\title{
Microbiological and Physicochemical Characterization of Honeys from the Tiaret Region of Algeria
}

\author{
Hocine Laredj ${ }^{* *}$ and Rezzoug Waffa ${ }^{2}$ \\ 'Laboratory of Agro-Biotechnology and Nutrition in Semi-Arid Areas, Faculty of Sciences of Nature and of Life, \\ University Ibn Khaldoun BP 78 Zaaroura Tiaret, Algeria; lar_hocine@yahoo.fr \\ 2Laboratory of Geomatics and Sustainable Development, Faculty of Sciences of Nature and of Life, \\ University Ibn Khaldoun BP 78 Zaaroura Tiaret, Algeria; rezzougwaffa@yahoo.fr
}

\begin{abstract}
Honey is an organic product with a multiple physicochemical and biological properties. Microbiological analysis (total search germs, coliforms and fecal coliforms, spores of sulfite-reducing, Clostridium botulinum and Bacillus cereus and research yeasts) showed that the samples studied contain no spores or coliform and fecal coliform. The physicochemical analyzes (water content, Hydroxymethylfurfural: HMF, pH and free acidity, conductivity electrical and ash) showed that all samples meet International standards with the exception of one sample showed an HMF content $(42.05 \mathrm{mg} / \mathrm{kg})$ which is slightly above the European norm but still consistent with the Codex Alimentarius. The result of analyzes show that different honeys produced in this region are of good hygienic and market qualities.
\end{abstract}

Keywords: Characterization, Honey, Microbiological, Physicochemical, Tiaret

\section{Introduction}

Honey is a food that mankind has known since antiquity. It is a mixture consisting mainly of water and sugars, also containing gluconic acid, lactones nitrogen compounds, minerals and vitamins ${ }^{1}$. The term quality in the specific case of honey is evaluated by a physicochemical and microbiological analysis of its constituents.

The International Honey Commission (IHC) and the Codex Alimentarius Standard for honey quality have proposed several chemical and physical parameters as quality criteria for honey. These include: moisture content, mineral content, acidity, hydroxymethylfurfural (HMF) content, diastase activity, apparent sugar content.

Honey, despite its richness in sugar and inhibins, is subject to bacterial or fungal contaminations which can cause its deterioration.

Honey has two sources of contamination with microorganisms: primary sources include pollen, the digestive tracts of honey bees, dust, air, soil and nectar; secondary sources are those arising from honey manipulation by people, they include air, food handlers, cross-contamination, equipment and buildings. Primary sources of honey contamination are very difficult to control. Conversely, secondary sources of honey contamination can be controlled by good manufacturing practices. The microbes of concern in honey are fungi, yeasts and spore-forming bacteria. Yeasts are responsible for honey fermentation when the moisture content is high $^{2}$. A number of bacteria are present in honey, most of them being harmless to humans ${ }^{3}$.

Honey has been incriminated as a source of Clostridium botulinum spores responsible for infant botulism cases ${ }^{4}$.

Microbiological testing should guarantee both a good hygienic and good marketable qualities of this product and good production efficiency.

In Algeria, Honey has been used more for medicinal and religious purposes than as a nutritional food. Only few studies have been developed at local level.

Thus, the aim of the present work is the 
physicochemical characterization of some honeys produced in the Tiaret region in Algeria, by the analysis of some common physicochemical parameters (water content, $\mathrm{pH}$, free acidity, ash, electrical conductivity and HMF), and microbiological characterization (Research of mesophilic aerobic flora and research of germs hygienic quality indicators such as coliforms, fecal coliforms and other bacteria whose presence is undesirable such as Clostridium botulinum, sulfite-reducing Clostridia and Bacillus cereus and yeast fermentation agent honeys ).

\section{Materials and Methods}

\subsection{Sample Collection}

Ten multifloral honey samples were randomly collected from beekeepers, in the city of Tiaret, Algeria. Samples (500 g of honey/sample) were transported aseptically to the laboratory for the study and distributed in sterile covers, sealed, labeled and stored at room temperatures $\left(20^{\circ} \mathrm{C}\right)$.

\subsection{Physicochemical Analysis}

\subsubsection{Moisture Content}

Water content (moisture) was determined following Chataway and a method established by the International Honey Commission ${ }^{5}$. We used an Abbe-type refractometer, obtaining the corresponding percentage of water from the Chataway table. All measurements were performed at $20^{\circ} \mathrm{C}$.

\subsubsection{Hydroxymethylfurfural Content}

According to the method of Winkler (1955) described in the report of the International Honey Commission ${ }^{5,6}$, ten grams of each of the samples were treated with a Carrez I and II (clarifying agent). The volume was completed to $50 \mathrm{ml}$ and the solution was filtered. The absorbance of solution was measured at $550 \mathrm{~nm}$.

\subsubsection{Electrical Conductivity (EC)}

The electrical conductivity was measured by analyzing a solution of $20 \mathrm{~g}$ of dry matter of honey dissolved in 100 $\mathrm{ml}$ of distilled water using a conductivity meter PHYWE instruments (1370193). EC values are expressed in milli Siemens per centimeter $\left(\mathrm{mS} . \mathrm{cm}^{-1}\right)^{6}$.

\subsection{4 $\mathrm{pH}$ and Free Acidity}

$\mathrm{pH}$ and free acidity were measured by the titrimetric method. $10 \mathrm{~g}$ of honey were dissolved in $75 \mathrm{ml}, \mathrm{CO}_{2}$-free distilled water. The electrode of the $\mathrm{pH}$ meter (HANNA 2211) was immersed in the solution, stirred and titrated with carbonate-free $0.10 \mathrm{NaOH}$ until the $\mathrm{pH}$ reached 8.56.

\subsubsection{Ash Content}

According to International Honey Commission ${ }^{5}$, Samples of 5-10 $\mathrm{g}$ were incinerated in a Muffle furnace at a temperature no higher than $600^{\circ} \mathrm{C}$ to constant weigh, cooled and the residue weighed. The result was expressed as $\mathrm{g}$ of $\mathrm{ash} / 100 \mathrm{~g}$ of honey.

\subsection{Microbiological Analysis}

\subsubsection{Pre-Treatment of Samples}

Ten grams of each sample were homogenized for $3 \mathrm{~min}$ in $90 \mathrm{ml}\left(10^{-1}\right.$ suspension $)$ peptone water. Ten-fold dilutions were prepared till $10^{-3}$.

\subsubsection{Count of Mesophilic aerobic flora at $30^{\circ} \mathrm{C}$}

Place $1 \mathrm{ml}$ of the microbial suspension in a petri dishes, add $12 \mathrm{ml}$ of plate count agar (PCA) medium, mix by rotating movements and let solidify. Place the Petri dishes in inverted position and incubate at $30^{\circ} \mathrm{C}$ for $72 \mathrm{~h}^{7-10}$.

\subsubsection{Detection of Coliforms and Fecal Coliforms}

According to Guiraud ${ }^{11}$, the counting is done by lactose agar with purple crystal and neutral red (VRBL). Put $1 \mathrm{ml}$ of solution in a sterile petri dish and add about $12 \mathrm{ml}$ of the culture medium (pre-cooled to $45^{\circ} \mathrm{C}$ ) and then mix all and let solidify; after solidification, incubated coliforms at $30^{\circ} \mathrm{C}$ and fecal coliforms at $44^{\circ} \mathrm{C}$ for 24 to $48 \mathrm{~h}$.

\subsubsection{Detection of Spores of Sulfite-Reducing Clostridia}

Melt in boiling water bath liver meat medium and cooling to about $65^{\circ} \mathrm{C}$. and then added to the medium $5 \mathrm{ml}$ of sodium sulfite and $2.5 \mathrm{ml}$ of iron alum (for a $250 \mathrm{ml}$ ); Place $5 \mathrm{ml}$ of stock solution (10 g honey/90 $\mathrm{ml}$ diluent) into a sterile tube and carry them to the water bath at $80^{\circ} \mathrm{C}$ for $10 \mathrm{~min}$ (destruction of vegetative forms) then rapidly cooled in water; filling the tube with the prepared 
medium and homogenize the mixture, incubated at $46^{\circ} \mathrm{C}$ during $24 \mathrm{~h}$ to $48 \mathrm{~h}$. The sulfite spores appear as colonies surrounded by a black halo ${ }^{11,12}$.

\subsubsection{Detection of Vegetative Cells of Bacillus cereus}

Bacillus cereus sought was performed on middle mossel. To $90 \mathrm{ml}$ of melted medium mossel and cooled to $50^{\circ} \mathrm{C}$, $10 \mathrm{ml}$ of a sterile emulsion of egg yolk with $20 \%$ and 1 $\mathrm{ml}$ of polymyxin sulphate solution $0.1 \%$ were added. Pour the mixture into petri dishes and allow to cool. Spread 0.1 $\mathrm{ml}$ of the dilution of the honey $\left(10^{-1}\right)$ on the surface of the culture medium and incubated at $30-35^{\circ} \mathrm{C}$ for $24 \mathrm{~h}$ to 48 h. count the pink colonies mannitol (-) surrounded by a white area (lecithinase +$)^{13,14}$.

\subsubsection{Detection of Clostridium botulinum Spores}

Take $25 \mathrm{~g}$ of honey in a sterile beaker. Add $100 \mathrm{ml}$ of distilled water containing $1 \%$ Tween 80 and mix until the suspension is homogeneous. Transfer $125 \mathrm{ml}$ from the honey slurry in centrifuge bottles of $300 \mathrm{ml}$. Place in a water bath at $65^{\circ} \mathrm{C}$ for $30 \mathrm{~min}$ and centrifuged at $15,000 \mathrm{~g}$ for 20 minutes .Filter the supernatant through a membrane filter Millex HA de 0,45 MF (millipore). Keep the sediment temporarily at $4^{\circ} \mathrm{C}$ and filter.

After filtration, rinse dilution bottle and the funnel with about $5 \mathrm{ml}$ of water sterile cold distilled and then filtered through the filter membrane. In a laminar flow hood, transferring the MF in $110 \mathrm{ml}$ of TPGYB medium (Trypticase-Peptone-Glucose-Yeast extractBeef extract). Carefully add the obtained sediment upon centrifugation at a dilution bottle containing the medium and the TPGYB filtered. Incubate at $35^{\circ} \mathrm{C}$ for 7 days under anaerobic conditions. Show the bottles daily. Culture was examined for turbidity, gas production and microscopic appearance. In the absence of growth, re-incubated for 10 additional days ${ }^{15,16}$.

\subsubsection{Yeast Counting Method}

The diluent is prepared by adding peptone water $(0.1 \%)$ and $40 \%$ glucose; the solution was stirred until complete dissolution of glucose and sterilized at $120{ }^{\circ} \mathrm{C}$ for 15 $\min ^{17,18}$. The honey solution is obtained by mixing $10 \mathrm{~g}$ of honey and $90 \mathrm{ml}$ of diluent, the solution should be stirred and allowed to stand.

The culture was performed on the media YM40G (Yeast, Malt, 40\% Glucose). This medium is intended to osmophilic yeasts. It consists in spreading $0.1 \mathrm{ml}$ of the solution on surface using the technique of the rake, the observations are made after 5-7 days of incubation at $30^{\circ} \mathrm{C}$ The result was expressed as $\mathrm{cfu} / \mathrm{g}^{17,18}$.

\section{Results and Discussion}

\subsection{Physicochemical Characteristics}

Table 1 shows various physicochemical parameters analyzed: Moisture content, HMF content, Ash content, electrical conductivity, $\mathrm{pH}$ and free acidity.

\subsubsection{Water Content}

The water content of the different honey samples varies from 14.4 to $19.7 \%$. Eight samples of honey (80\%) have water content less than $18 \%$; limit value for fermentation

Table 1. Physicochemical characteristics of honey samples

\begin{tabular}{lcccccc}
\hline $\mathbf{N}^{\circ}$ sample & $\begin{array}{c}\text { Moisture } \\
\text { content }(\%)\end{array}$ & $\begin{array}{c}\text { HMF content } \\
(\mathbf{m g} / \mathbf{k g})\end{array}$ & $\begin{array}{c}\text { Ash content } \\
(\mathrm{g} / \mathbf{1 0 0 g})\end{array}$ & $\begin{array}{c}\text { Electrical conducti- } \\
\text { vity }(\mathrm{mS} / \mathrm{cm})\end{array}$ & $\mathrm{pH}$ & $\begin{array}{c}\text { Free acidity } \\
(\mathrm{meq} / \mathrm{g})\end{array}$ \\
\hline 01 & 15 & 4.6 & 0.16 & 0.454 & 4.7 & 21.3 \\
02 & 17 & 9,6 & 0.11 & 0.432 & 4.19 & 24.1 \\
03 & 17 & 4,6 & 0.25 & 0.512 & 5.18 & 17.7 \\
04 & 17 & 23 & 0.09 & 0.222 & 3.8 & 31.2 \\
05 & 19.7 & 14.24 & 0.054 & 0.309 & 3.23 & 35.25 \\
06 & 15.28 & 14.01 & 0.02 & 0.292 & 3.12 & 38 \\
07 & 14.4 & 11.52 & 0.13 & 0.419 & 4.3 & 22 \\
08 & 15.9 & 6.53 & 0.166 & 0.49 & 4.9 & 18.8 \\
09 & 15.28 & 42.05 & 0.242 & 0.58 & 5.1 & 18.45 \\
10 & 19 & 28.8 & 0.056 & 0.223 & 3.5 & 31.5 \\
\hline
\end{tabular}


risk $^{19}$. All samples have water content less than $20 \%$, value fixed by the Codex Standards ${ }^{20}$ and the Council of the European Union Commission ${ }^{21}$.

The water content is one of the most important characteristics of honey, because it plays an important role in its quality and shelf-life of honey ${ }^{22,23}$.

\subsubsection{Hydroxymethylfurfural Content}

Although there is a disparity in the values obtained for the HMF of the various honeys (4.6 to $42.05 \mathrm{mg} / \mathrm{kg}$ ), the HMF levels of the majority of the honeys studied do not exceed $40 \mathrm{mg} / \mathrm{kg}$ (standard given by the European Union $)^{20}$ except for the sample $\mathrm{N}^{\circ} 9$ with a slightly higher value. This is probably due to a slight heating exerted by the beekeeper during the extraction or storage at high temperature. Moreover, for all samples, HMF contents are well below the threshold of tropical countries (80 $\mathrm{mg} / \mathrm{kg}$ ) given by Codex Alimentarius ${ }^{20}$. About $50 \%$ of samples studied have very low values $(<10 \mathrm{mg} / \mathrm{kg})$; indicating that these honeys have been freshly harvested ${ }^{24}$ or were not heated and were well stored ${ }^{5,25}$. According to Bogdanov et $a .^{19}$, fresh honey contains substantially no Hydroxy-Methylfurfural (HMF), its content increases during storage, depending on the $\mathrm{pH}$ of the honey and the storage temperature.

\subsubsection{Electrical Conductivity (EC)}

The electrical conductivity of the analyzed honeys varied from 0.222 to $0.580 \mathrm{mS} / \mathrm{cm}$; these values remain in the range of 0.1 to $0.5 \mathrm{mS} / \mathrm{cm}$ for flower honeys except for samples $\mathrm{N}^{\circ} 3$ and 9 which could correspond to a mixture of nectar and honeydew ${ }^{26}$. However, a classification of our values allows us to distinguish two classes of honeys probably having the same floral origin ${ }^{27}$ : class 1 : samples $\mathrm{N}^{\circ}$ 4, 5, 6 and 10, class 2: samples $\mathrm{N}^{\circ} 1,2,3,7,8$ and 9 (Table 1). Although the EC is a characteristic of the plant species from which the honey comes, it is also proportional to the amount of ash and acidity of honey ${ }^{28-30}$. Conductivity is an interesting parameter because it is easy to distinguish honeydew honey from flower honeys ${ }^{31}$. In general, the honeydew honeys conduct much better current than the flower honeys ${ }^{27}$.

\subsection{4 pH and Free Acidity}

The $\mathrm{pH}$ values are ranged from 3.12 to 5.18 (Table 1). All samples of honey studied are acid; these values agree with those reported by White and his collaborators ${ }^{32}$ whose $\mathrm{pH}$ range from 3.5 to 5.5 due to the presence of organic acids. According to Schweitzer ${ }^{33}$, the most acid honeys deteriorate quickly. Variations in $\mathrm{pH}$ can be attributed to diversity of melliferous plants in the Tiaret region. Indeed, honey nectars have $\mathrm{pH}$ of 3.5 to $4.5 \mathrm{vs}$. honeydew honeys with a $\mathrm{pH}$ between 5 and $5.5^{19}$. These observations confirm the results of the electrical conductivity where all honeys studied are of nectarifer origin; except samples $\mathrm{N}^{\circ} 3$ and 9 which have $\mathrm{pH}>4.5$. The free acidity of the samples varies between 17.7 and $38 \mathrm{meq} / \mathrm{kg}$. These values are well below the limit $(50 \mathrm{mEq} / \mathrm{kg})$ recommended by the harmonized methods of the European Commission ${ }^{6}$. Furthermore, samples $\mathrm{N}^{\circ} 4,5,6$ and 10 have values in free acidity> $30 \mathrm{mEq} / \mathrm{kg}$; this could be explained by some acids from the digestive secretions of bees during the elaboration of honey or make them susceptible to alteration by fermentation ${ }^{34}$.

\subsubsection{Ash Content}

For the majority of honeys, the ash contents are ranged from 0.02 to $0.16 \%$; values do not exceed $0.2 \%$ for the category of nectar honeys ${ }^{35}$. Samples $\mathrm{N}^{\circ} 3$ and 9 with the values of 0.25 and $0.24 \%$ respectively, included them in the range of 0.2 to $1 \%$ corresponding to honey obtained from nectar and honeydew mixture ${ }^{35}$. Bogdanov and collaborators $^{19}$ reported that the ash content is a quality criterion that depends on the botanical origin of the honey. The values obtained for the ash are in conformity with those found for the EC. It has been reported that EC is sufficient for routine controls in determining botanical origin $^{24}$. The variability of the ash content observed for the different honeys (Table 1.) could also be due to the number of pollinated plants, soil type and processes and beekeeping techniques used ${ }^{36,37}$.

\subsection{Microbiological characteristics}

Table 2 shows various Microbiological results: Coliforms and Fecal Coliforms, sulfite-reducing anaerobes, Bacillus cereus spores, Clostridium botulinum spores and Yeast.

\subsubsection{Mesophilic Aerobic Flora at $30^{\circ} \mathrm{C}$}

The detection of the mesophilic aerobic flora reflects the general microbiological quality of the natural products and allows controlling them ${ }^{9}$. The absence of standards for the microbiological analysis of honeys makes 
Table 2. Microbiological results (in colony forming units per gramme: $\mathrm{cfu} / \mathrm{g}$ )

\begin{tabular}{lcccccc}
\hline $\mathbf{N}^{\circ}$ sample & $\begin{array}{c}\text { Mesophilic } \\
\text { aerobic flora }\end{array}$ & $\begin{array}{c}\text { Coliforms and } \\
\text { Fecal Coliforms }\end{array}$ & $\begin{array}{c}\text { Sulfite-reducing } \\
\text { anaerobes }\end{array}$ & $\begin{array}{c}\text { Bacillus } \\
\text { cereus }\end{array}$ & $\begin{array}{c}\text { Clostridium } \\
\text { botulinum }\end{array}$ & Yeasts \\
\hline 01 & 1416 & 0 & 0 & 0 & 0 & 960 \\
02 & 87 & 0 & 0 & 0 & 0 & 30 \\
03 & 770 & 0 & 0 & 0 & 0 & 620 \\
04 & 1050 & 0 & 0 & 20 & 0 & 875 \\
05 & 170 & 0 & 0 & 0 & 0 & 100 \\
06 & 10 & 0 & 0 & 0 & 0 & 4 \\
07 & 100 & 0 & 0 & 0 & 0 & 77 \\
08 & 340 & 0 & 0 & 0 & 0 & 110 \\
09 & 410 & 0 & 0 & 0 & 0 & 100 \\
10 & 180 & 0 & 0 & 0 & 0 & 60 \\
\hline
\end{tabular}

interpretation difficult ${ }^{18}$. The total number of mesophilic range of 10 to $1.410^{3} \mathrm{cfu} / \mathrm{g}$ (Table 2). Most honeys studied have a count below $500 \mathrm{cfu} / \mathrm{g}$; quality limit value recommended by Fleché et al..$^{38}$. Honey is not subject to the development of germs compared to other foods, due to its high sugar content, low water activity, low $\mathrm{pH}$ and antimicrobial substances ${ }^{39}$. Although samples 1,3 and 4 have high numbers respectively of $1.410^{3}, 7.710^{2}$ and $1.110^{3} \mathrm{cfu} / \mathrm{g}$ compared with the limit value, they are less exposed to bacterial alterations due to their moisture content below 18\% (Table 1). The origin of contamination by the mesophilic aerobic flora in these honeys result from possible contamination during processing, handling and storage or of the normal flora of the gastrointestinal tract of bees ${ }^{40}$.

\subsubsection{Coliforms and Fecal Coliforms}

For the 10 samples of honey analyzed, there is a total absence of coliforms and fecal coliforms, these results agree with those found by Omafuvbe and Akanbi ${ }^{41}$, Naman et $a l .^{42}$, this is explained by the fact that honey is an environment hostile to the development of this flora and indicates that our honeys are of good hygienic quality.

\subsubsection{Spores of Sulfite-Reducing Clostridium}

The presence of Sulfite-reducing Clostridium in honey can be considered as an indicator of contamination ${ }^{43}$. The spores of sulfite-reducing Clostridium were not detected in any sample, indicating that honeys were produced in accordance with good hygiene practices during extraction, packaging and storage ${ }^{11}$.

\subsubsection{Bacillus cereus}

Only Sample $\mathrm{N}^{\circ} 4$ contains $20 \mathrm{cfu} / \mathrm{g}$ of Bacillus cereus (Table 2), a very low result compared to those obtained by Martins et al. ${ }^{44}$, with maximum of $10^{4} \mathrm{cfu} / \mathrm{g}$. Exceeding $10^{5} \mathrm{cfu} / \mathrm{g}$ a toxigenic risk is possible ${ }^{39,44,45}$. According to Fleché ${ }^{38}$, Bacillus in honey are part of the mesophilic flora induced by the bee (nectar or honeydew).

\subsubsection{Clostridium botulinum Spores}

The results for all the honeys studied showed no spore of Clostridium botulinum in both culture media (Table 2). These results are consistent with those of Huhtanem et al. ${ }^{46}$ carried out on 80 samples of honey. Other studies have reported low numbers of Clostridium botulinum Spores, i.e., 2 spores for 100 samples ${ }^{47}$ and 6 spores for 48 samples ${ }^{15}$.

\subsubsection{Yeasts}

The number of yeasts varies from 4 to $960 \mathrm{cfu} / \mathrm{g}$, their origin is exogenous and could come from: nectar, bees (paws, tongues, craw) and contamination during extraction ${ }^{27,38}$. The samples $\mathrm{N}^{\circ} 1,3$ and 4 , with a high number of yeasts; 960,620 and $875 \mathrm{cfu} / \mathrm{g}$ respectively, are not subject to any fermentation risk since their moisture content is $\leq 17 \%$ (Table 1). In contrary, samples $\mathrm{N}^{\circ} 5$ and 10 , with a lower number of yeasts (100 and $60 \mathrm{cfu} / \mathrm{g}$ respectively) but with water contents $\geq 19 \%$ are subject to the fermentation risks $^{48,49}$. This risk can be detected by the yeast count ${ }^{50}$. If only the number of yeasts is taken into account, there is a disparity between the values of the different samples, a 
distribution of our results according to the limits reported by Fleché et $a l .{ }^{38}$ regarding the conservation of honey, allows to distinguish two classes:

- Seven samples $\left(\mathrm{N}^{\circ} 2,5,6,7,8,9\right.$ and 10) contain approximately $100 \mathrm{cfu} / \mathrm{g}$ : good conservation of honey.

- The samples $\mathrm{N}^{\circ} 1,3$ and 4 with values between 500 and $1000 \mathrm{cfu} / \mathrm{g}$ : honeys start to ferment.

\section{Conclusion}

The physicochemical and microbiological analytical results of honeys produced in Tiaret region (Algeria), indicate a good level of quality.

The values of HMF and free acidity were very satisfactory showing good quality of these honeys. The exception is for sample 9, which has an HMF value slightly higher than the European standard but remains below the Codex Alimentarius standard for hot countries (Tiaret is characterized by a warm and dry climate in summer, period of the first harvests of the honey)

The $\mathrm{pH}$ of the honey studied is acidic. Three samples have values greater than 4.5 and can therefore have a honeydew origin. While others, may have a floral origin. Water content is lower than European and international standards.

The electrical conductivity and ash values are low and consistent with one another. According to most scientists the electrical conductivity is strongly related to the mineral content.

The result of the microbiological analyzes show that the samples studied are of very good microbiological and hygienic quality. Nevertheless, some samples have high yeast contents but with water contents of less than $18 \%$ and can constitute a fermentation risk if the storage conditions are not respected.

\section{Acknowledgement}

We would like to thank Ms. Gourchala Freha and Mihoub Fatma, teachers' researchers at Ibn Khaldoun University at the Faculty of Nature and Life Sciences for their help and scientific contributions.

\section{References}

1. White JWJr. Honey. Advances in Food Research. 1983; (24):287-374.
2. Louveaux J. Les abeilles et leurs élevages. Ed OPIDA; 1985. p. 265.

3. Zucchi P, Bassignani V, Carpana E. Honey microbiology. Industrie Alimentari. 2001; 40(409):1346-50.

4. Amon SS, Damus K, Chin J. Infant botulism: epi-demiology and relation to sudden infant death syndrome. Epidemiol Rev. 1981; (3):45-66.

5. International honey commission. Harmonized Methods of the International Honey Commission. 2009; 1-63. http:// www.bee-hexagon.net/en/network.htm

6. Bogdanov S, Martin P, Lullmann C, Borneck R, Flamini C, et al. Harmonised methods of the European honey commission. Apidologie. (Extra issue): 1997; 1-59.

7. Bekelle B, Tetemke M, Mogessie A. Yeast and lactic acid flora of tej, indigenous Ethiopian honey wine, variations with in and between production. Addis Ababa Ethiopia ; 2007. $1-3$.

8. Delarras C. Microbiologie de l'environnement avec législation. Europe, Paris: Gaétan Morin Editeur; 2000. p. 1-74.

9. Guiraud JP, Rosec JP. Pratique des normes en microbiologie alimentaire. AFNOR ; 2004. 1-96.

10. Normes Internationale ISO 4833. Méthode pour le dénombrement de germes aérobies en milieu solide; 1993. p. 3.

11. Guiraud JP. Microbiologie alimentaire. Paris: Dunod ; 2003. p. 401-15.

12. Petransxiene D, Lapied L. La qualite bactériologique du lait et des produits laitiers, analyses et tests. 2nd ed. Paris: Technique et Documentation, LAVOISIER; 1981. p. 228.

13. Guillaume P. Mictobiologie. Les milieux de culture; 2004. www.ac-lyon.fr/enseigne/biotech/microbio

14. Larpent-Gourgaud M, Larpent JP. Mémento technique de microbiologie. Lavoisier, Tec et Doc; 1997.

15. Kuplulu O, Goncuoglu M, Ozdemir H, Koluman A. Incidence of Clostridium botulinum spores in honey in Turkey. Food Contol. 2006; (17):222-4.

16. Solomon HM, Lilly TJr. Clostridium botulinum. Bacteriological Analytical Manual. 8th Ed. 2001. Available from: http://vmcfsan.fda.gov/ ebam/bam-toc.html

17. Douey D, Wilson P. Dénombrement des levures et des moisissures dans les aliments in agence canadienne d'inscription des aliments Direction des aliments. Santé CANADA. 2004; 1-19.

18. Ward WH, Trueman KF. A quality survey of Australian Honeys. Ed: RIRDC. 2001; 1-41.

19. Bogdanov S, Bieri K, Gremaud G, Iff D, Känzig A, Seiler K, Stöckli H, Zürcher K. Produits apicoles. 23A Miel. Revue par le groupe d'experts "produits apicoles". MSDA. 2004; $1-37$.

20. Codex Alimentarius. Codex standard 12, Revised Codex Standard for Honey, Standards and Standard Methods. FAO- Rome ; 2001. p. 1-7. http://www. codexalimentarius. net

21. The Council of the European Union. Council Directive $2001 / 110 /$ ec of 20 december relating to honey. Official Journal of the European Communities. 2002; (10):47-52.

22. Bruneau E. Voyage au cœur du miel, l'essentiel du pro- 
gramme européen de miel. Resp, CARI, Louvain- La neuve. 2006; $2-4$.

23. Terrab A, Diez MJ, Heredia FJ. Palynological, physicochemical and colour characterization of Moroccan honeys. II. Orange (Citrus sp.) honey. International Journal of Food Science and Technology. 2003; (38):387-94. https://doi. org/10.1046/j.1365-2621.2003.00714.x

24. Bogdanov S, Rouff K, Persano-Oddo L, Physico-chemical methods for the characterisation of unifloral honeys: A revieu. Apidologie. 2004; (35):4-17. https://doi.org/10.1051/ apido:2004047

25. Levantes MAR, Novelo SAG, Duch ES. Les effets du traitement thermique sur la qualité du miel pendant l'entreposage. Apiacta. 2000; 35(4):162-70.

26. Jean-Prost P, Medori P. Apiculture: Connaitre l'abeille conduire le rucher. Paris : J. B. Baillière; 1987.

27. Gonnet M. Le miel: Composition. Propriété et conservation. OPIDA-INRA; 1982.

28. Bogdanov S, Bieri K, Kilchemann V, Gallmann P. Miels monofloraux Suisses. ALP forum N²3F. 2005; 55.

29. Terrab A, Diez MJ, Heredia FJ. Characterization of Moroccan unifloral honeys by their physicochemical characteristics. Food Chemistry. 2002; (79):373-9. https://doi. org/10.1016/S0308-8146(02)00189-9

30. Terrab A, Recamales AF, Hernanz D, Heredia FJ. Caracterisation of Spanish thyme honeys by physicochemical characteristics and mineral contents. Food Chemistry. 2004; (88):537-42. https://doi.org/10.1016/j. foodchem.2004.01.068

31. Bogdanov S, Bieri K. Miels monofloraux suisses. Station de recherche Agroscope liebefeld-posieux ALP. 2008; 1-56.

32. White JW, Petty J, Hoger R. Composition of honey II. Lactone content. J AOAC. 1958; 41. PMid:13561914.

33. Schweitzer P. Les critères de qualité du miel. CETAM -Lorraine. Revue l'abeille de France; 2004. No 908.

34. Louveaux J. Composition de technologie du miel. in traité de la biologie de l'abeille. Tome 3: les produits de la ruche; Paris: Ed. Masson et CIE; 1968. 277-318.

35. Donadieu Y. Qu'est ce que le miel? Faculté de médecine, Paris; 2004. p. 1-6.

36. Huchet E, Coustel J, Guinot L. Les constituants chimiques du miel, méthodes d'analyses chimiques. Departement Sciences de l'aliment; 1996. p. 1-5.

37. Monica S, Mirta F, Lasango C, Marioli JM. Microbiological and chemical characterization of honeys from central Ar- gentina, Departamentos de Quimica y de 10-Microbiologia e Inmunologia, Facultad de Ciencias Exactas, Fisicoquimicas y Naturales, Universidad Nacional de Rio Cuarto. Food Chemistry. 2007; 100:1649-953.

38. Fleche M, Clement C, Zeggane S, Faucon JP. Contamination des produits de la ruche et risque pour la sante humaine. situation en France. Rev SCI TECH INT Epiz. 1997; 609-12.

39. Snowdon JA, Cliver DQ. Micro-organisms in honey. International Journal of Food Microbiology. 1996; (31):1-26. https://doi.org/10.1016/0168-1605(96)00970-1

40. Kacaniova M., Chlebo R., Kopernicky M., Trakovicka A. Microflora of the honeybee gastrointestinal tract. Folia Microbiol. 2004; (49):169-71. https://doi.org/10.1007/ BF02931394

41. Omafuvbe BO, Akanbi OO. Microbiological and physico-chemical properties of some commercial Nigerian honey. African Journal of Microbiology Research. 2009 Dec; 3(12):891-6.

42. Naman M., Faid M, El adlouni C. Microbiological and physico-chemical properties of moroccan honey. Int J Agri Biol. 2005; (7):773-6.

43. Collins CH, Lyne PM, Grange JM. Collins and Lyne's microbiological methods. 7th ed. Oxford: Butterworth-Heinemann; 1999. p. 213-21.

44. Martins HM, Martins ML, Bernardo FMA. Bacillaceae spores, fungi and aflatoxins determination in honey. Revista Portuguesa De Ciências Vet- erinárias. 2003; 98(546) :85-8.

45. Jouve L. La qualité microbiologique des aliments maîtrise et critères, 2eme ed. Paris: Polytechnica; 1996; p. 186-354.

46. Huhtanen CN, Knox D, Shimanuki H. Incidence and Origin of Clostridium botulinum Spores in Honey. J Food Protection. 1981; (44):812-4. https://doi.org/10.4315/0362028X-44.11.812

47. Kautter DA, Timothey LJr, Solomon HM, Lynt RK. Clostridium botulinum Spores infant foods: A survey. J Food Protection. 1982; (45):1028-9. https://doi.org/10.4315/0362028X-45.11.1028

48. Merlet PY. Le miel. These de doctorat veterinaire. Toulouse : Universite Paul Sabatier; 1981. p. 153.

49. Bogdanov S, Martin P. Honey authenticity: A review. Swiss Bee Research Centre; 2002. p. 1-20.

50. Beckh G, Lüllmann C. Les composants naturels de miel Levures et leur Métabolites. Tel 1: teneur en levure. Dtsch. Lebensm. Psychosom. 1999; (95):457-63. 